\title{
Genetic Diversity of Armillaria spp. Infecting Highbush Blueberry in Northern Italy (Trentino Region)
}

\author{
D. Prodorutti, T. Vanblaere, D. Gobbin, A. Pellegrini, C. Gessler, and I. Pertot
}

First, fourth, and sixth authors: Plant Protection Department, Fondazione Edmund Mach, S. Michele all'Adige TN 38010, Italy; second and third authors: SafeCrop Centre, S. Michele all'Adige TN 38010, Italy; and fifth author: Department of Plant Pathology, Institute of Integrative Biology, ETH, Zürich, Switzerland.

Accepted for publication 31 January 2009.

\begin{abstract}
Prodorutti, D., Vanblaere, T., Gobbin, D., Pellegrini, A., Gessler, C., and Pertot, I. 2009. Genetic diversity of Armillaria spp. infecting highbush blueberry in northern Italy (Trentino region). Phytopathology 99:651-658.

Armillaria spp. are the causal agents of root rots of several woody plants, including highbush blueberry. Since 2003, highbush blueberry plants infected by Armillaria spp. have been found in Valsugana Valley, Trentino region, northern Italy. Our aim was to identify the Armillaria spp. involved in these infections, as well as possible sources of inoculum in blueberry fields. Samples of Armillaria spp. were collected from diseased blueberry plants in 13 infected blueberry fields, from bark spread along the blueberry rows, from infected trees in the vicinity of the fields, and from four forest locations. The identification of Armillaria

spp. was accomplished using a species-specific multiplex polymerase chain reaction method and by sequencing the rDNA at a specific locus. The differentiation between genotypes was performed by using simplesequence repeat analysis. Armillaria mellea and A. gallica were the most frequently observed species infecting blueberry in the Valsugana Valley. Three to eight Armillaria genotypes were identified in each blueberry field. No individual genotypes were found in more than one blueberry field. Two-thirds of the genotypes found colonizing trees in the immediate vicinity of infected fields and two-thirds of the genotypes found colonizing the bark spread in blueberry rows were also isolated from blueberry plants in the field, indicating that bark used as mulch and infected trees surrounding the fields may be important sources of inoculum.
\end{abstract}

The Basidiomycetous genus Armillaria includes several species that live mostly as saprotrophs on wood and root debris in the soil (7). However, they also show variable degrees of pathogenicity and cause root rot on woody plants, including highbush blueberry (Vaccinium corymbosum L.) (4).

On blueberry, in the first stage of the disease, Armillaria spp. cause reduced plant vigor and infected plants develop small chlorotic leaves that redden prematurely in autumn. Later, the roots rot and the branches wilt. Infected plants usually die within a few months. White fan leaf mycelium is typically observed under the outer surface of the roots and rhizomorphs can be found inside and around the rotted roots. In fields and vineyards, the disease usually appears in patches of different dimensions, suggesting that the disease spreads through the soil, mainly via rhizomorphs originating from different inoculum sources $(3,18,21)$. Genetic individuals, or genets, of Armillaria spp. are usually found in discrete patches that often include the root systems of several adjacent trees. Each dikaryotic (diploid) individual is thought to arise from a unique mating event and then grow vegetatively over a long period of time, across an ever-expanding area (23).

The Piedmont and Trentino regions are the main areas of highbush blueberry cultivation in Italy. In 2006, in the Trentino region of northern Italy, highbush blueberry was cultivated on an area of 69.65 ha, mostly ( $\approx 60 \mathrm{ha}$ ) in the Valsugana Valley, at altitudes of 400 to $1,000 \mathrm{~m}$ above sea level. In this region, blueberry bushes are planted in marginal agricultural areas close to the forest as well as in areas of intensive horticultural activity. The most common cultivar is Brigitta Blue (42 ha), followed by Elliot (6 ha). Blueberry plantations are small, with cultivated surface areas of

Corresponding author: D. Prodorutti; E-mail address: daniele.prodorutti@iasma.it

doi:10.1094/PHYTO-99-6-0651

(C) 2009 The American Phytopathological Society
500 to $5,000 \mathrm{~m}^{2}$. Plants are usually cultivated in rows and mulched with a deep layer (at least $10 \mathrm{~cm}$ ) of coniferous bark. This bark is usually collected by the grower in the nearby forests. Bark is often kept for several months in heaps on the edges of the fields and new bark is added to the rows every 2 to 3 years, as the older bark decays.

In 2003, highbush blueberry plants showing typical symptoms of Armillaria rot root were first unequivocally identified in the Valsugana Valley. Fungal samples isolated from symptomatic plants were identified as Armillaria gallica Marxm. \& Romagn. and shown to be the causal agent of the observed disease symptoms (20). Other than in Italy, Armillaria spp. have been reported to be pathogens of highbush blueberry in the United States. Specifically, A. mellea (Vahl) P. Kumm. and A. ostoyae (Romagn.) Herink have been isolated from infected plants in the United States (4).

Armillaria spp. infections in newly planted fields and vineyards often occur after forest trees or old plants with Armillaria root disease have been removed. In fact, infected roots that remain in the ground serve as a source of inoculum for infections of plants planted in these fields in later seasons (18). Coniferous bark is a good substrate for the development of Armillaria spp. (17). This implies that Armillaria spp.-infected bark used as mulch may represent another potential source of inoculum. The movement of soil, root and wood debris, infected plants, and tools and farm machinery from infected to uninfected areas may also help spread this disease. The infection in a vineyard or orchard can also originate from rhizomorphs that have grown from infected trees and stumps in the immediate vicinity.

No effective control agents are available for use against Armillaria spp. (1). Only agronomic practices, such as uprooting and removing all infected roots, long rotations, and fallowing rotations that allow the degradation of all infected root debris may help reduce the availability of Armillaria inoculum and the risk of new blueberry plants becoming infected (4). 
The aims of this research were to (i) identify the Armillaria spp. infecting highbush blueberry in the Valsugana Valley and (ii) determine the potential sources of inoculum in and around blueberry fields. To investigate those issues, a species-specific multiplex polymerase chain reaction (PCR) was developed and a genetic analysis based on microsatellite typing was conducted on samples of Armillaria spp. collected in the Valsugana Valley.

\section{MATERIALS AND METHODS}

Identification of infected highbush blueberry fields, monitoring of disease development, and collection of samples of Armillaria spp. The study was conducted in the Valsugana Valley, which is home to $\approx 350$ blueberry fields. Two fields (05BV and 08BV) in which Armillaria root rot was first reported were monitored annually (in October) from 2003 through 2006, to assess the presence of symptomatic plants and plants that had been killed by Armillaria spp. in order to evaluate the development of the disease over time. Between June and September 2006, fields potentially infected by Armillaria spp. (plants displaying poor shoot growth, premature reddening, and dieback) were identified based on information provided by local growers and crop advisors. We inspected all of these potentially infected fields to verify the presence of signs of Armillaria root rot (mycelial fans and Armillaria rhizomorphs on roots). In October 2006, when aerial symptoms of root rot became more evident (premature reddening of leaves), the numbers and the percentages of stunted and dead plants in each of these fields were recorded. The presence of Armillaria spp. in stunted and dead plants was confirmed by removing the bark from the roots and root collars to expose any mycelial fans and rhizomorphs that might be present. For each of the examined fields, records were also collected concerning (i) the blueberry cultivar, the year of transplanting, and the year in which the first Armillaria symptoms were recorded by the grower; (ii) the possible inoculum sources inside and in the immediate vicinity of the cropped area (infected trees or stumps, bark heaps, or bark spread along the crop rows); (iii) the previous crop and the type of vegetation surrounding the blueberry crop; and (iv) whether the roots and stumps of the previous crop had been buried in the field (Table 1).

In October 2006, fungal samples (pieces of mycelial fans and rhizomorphs) were collected from infected plants in the selected fields (Fig. 1), after removing the bark from the blueberry roots and root collars to expose the pathogen. At least two samples were collected from each infected patch (defined as a group of at least two infected plants near one another) in each field. If present, samples of Armillaria spp. were also collected from bark used as mulch in the blueberry rows and from the bark heaps that are sometimes found at the edge of blueberry fields. Other plant species growing close to the blueberry fields and infected by Armillaria spp. were sampled as well. The sites in the forests from which growers usually collect bark to spread on blueberry fields were visited and checked for the presence of mycelial fans and rhizomorphs of Armillaria spp. Samples were collected from four main forest locations (forest 21- and 22BV and 21- and $22 \mathrm{AV})$. The samples were stored at $-80^{\circ} \mathrm{C}$ until they could be analyzed.

DNA extraction. Mycelia or rhizomorphs of Armillaria spp. from the above samples were freeze dried and homogenized in an MM300 homogenizer (Retsch, Haan, Germany). DNA was extracted from 3 to $10 \mathrm{mg}$ of mycelia or rhizomorphs, as described by Gobbin et al. (8) for their high-throughput method, using NucleoSpin multi-96 kits (Macherey-Nagel, Düren, Germany) according to the manufacturer's instructions. Instead of one final elution step of $180 \mu \mathrm{l}$, two elutions of $90 \mu \mathrm{l}$ each were performed.

Multiplex PCR for the identification of Armillaria spp. A multiplex PCR reaction for differentiating between A. mellea, A. gallica, and A. ostoyae was set up. Armillaria $18 \mathrm{~S}$ rRNA, internal transcribed spacer 1 (ITS1), 5.8S rRNA, ITS2, and 28S rRNA sequences deposited in the National Center for Biotechnology Information (NCBI) GenBank with the accession codes AY213587 and AY509188 (A. mellea); AY213571, AY509172, and AY509173 (A. gallica); AY213554, AY509156, and AY509157 (A. ostoyae); AY781248 (A. borealis Marxm. \& Korhonen); and AY213590 (A. tabescens (Scop.) Emel.) were aligned using ClustalW (28). The universal Armillaria primer pair AITSF/ AITSR was designed based on conserved regions common to all five previously mentioned Armillaria spp. For the identification of A. mellea, the primer combination AMEL3/ITS4 was used (25). The primer pairs AgPR1F/AgPR1R and AoPR1F/AoPR1R were designed based on species-specific polymorphic regions of $A$. gallica and $A$. ostoyae, respectively (Table 2). Primer specificity was tested using $5 \mu \mathrm{l}$ of DNA extracted from the first elutions of

TABLE 1. Fields with Armillaria spp.-infected blueberry plants in the Valsugana Valley (Trentino, Italy) $)^{\mathrm{y}}$

\begin{tabular}{|c|c|c|c|c|c|c|c|}
\hline Code & Location & Cultivar & $\begin{array}{l}\text { Planting } \\
\text { year }\end{array}$ & $\begin{array}{l}\text { Symptom } \\
\text { year }^{\mathrm{z}}\end{array}$ & Possible inoculum sources & Previous crop & $\begin{array}{l}\text { Surrounding } \\
\text { fields }\end{array}$ \\
\hline $01 \mathrm{AV}$ & Field & Brigitta Blue & 1997 & 5 & Hazelnut, walnut stumps & Blackberry & Forest/fields \\
\hline 02AV & Field & Brigitta Blue/Elliot & 2003 & 3 & $\begin{array}{l}\text { Chestnut trees/stumps, bark mulch, } \\
\text { bark heap }\end{array}$ & Meadow, chestnut & Forest \\
\hline 01BV & Field & Brigitta Blue & 1998 & 3 & Bark mulch & Pear & Fields \\
\hline 02BV & Field & Brigitta Blue & 1997 & 4 & $\ldots$ & Pear, meadow/pasture & Fields \\
\hline 03BV & Field & Brigitta Blue & 2003 & 3 & Plum tree, bark mulch & Meadow/pasture & Fields \\
\hline 04BV & Field & Brigitta Blue & 2000 & 4 & Bark mulch, bark heap & Meadow/pasture & Fields \\
\hline 05BV & Field & Brigitta Blue & 1999 & 3 & Cherry trees/stumps, bark mulch & Meadow, vineyard & Fields/meadow \\
\hline 06BV & Field & Brigitta Blue & 2001 & 4 & Chestnut, hazelnut trees, bark mulch & Forest, chestnut (buried roots and stumps) & Forest \\
\hline 07BV & Field & Brigitta Blue & 1997 & 5 & Cherry trees & Potato, cherry and plum & Fields/meadow \\
\hline 08BV & Field & Brigitta Blue & 2000 & 3 & Bark mulch & $\begin{array}{l}\text { Black locust, hazelnut (buried roots and } \\
\text { stumps) }\end{array}$ & Forest/fields \\
\hline 09BV & Field & Brigitta Blue & 2000 & 5 & $\ldots$ & Strawberry, zucchini & Fields/meadow \\
\hline 10BV & Field & Elliot & 2002 & 3 & $\ldots$ & Black locust, hazelnut, meadow & Forest \\
\hline $11 \mathrm{BV}$ & Field & Brigitta Blue & 2000 & 4 & Bark mulch & Meadow/pasture & Forest \\
\hline $21 \mathrm{AV}$ & Forest & $\ldots$ & $\ldots$ & $\ldots$ & Infected barks and logs & Forest & Forest \\
\hline $22 \mathrm{AV}$ & Forest & $\ldots$ & $\ldots$ & $\ldots$ & Infected barks and logs & Forest & Forest \\
\hline 21BV & Forest & $\ldots$ & $\ldots$ & $\ldots$ & Infected barks and logs & Forest & Forest \\
\hline 22BV & Forest & $\ldots$ & $\ldots$ & $\ldots$ & Infected barks and logs & Forest & Forest \\
\hline
\end{tabular}

y Samples of Armillaria spp. were collected in 2006 from blueberry plants in the fields, from possible inoculum sources inside and in the immediate vicinity of the cropped area (infected trees/stumps, bark mulch, or bark heaps), and from forest sites, where growers collect bark to spread on their blueberry fields. The blueberry cultivar, year of transplanting, appearance of the first Armillaria root rot-like symptoms (recorded by the grower), possible sources of inoculum, previous crop, and type of vegetation surrounding the blueberry crop are indicated.

z Year after planting that first symptoms were noted. 
A. mellea CBS 102.91, A. mellea 18A and 18B (18), A. tabescens CBS 129.26, A. ostoyae ATCC 66009, and A. gallica 14A and 27A (18). The PCR mixture (final volume of $20 \mu \mathrm{l}$ ) consisted of the following reagents: $1 \times$ Qiagen Multiplex PCR Master mix containing HotStarTaq DNA Polymerase (Qiagen, Milano, Italy) and a primer mix consisting of $0.2 \mu \mathrm{M}$ AgPR1F/AgPR1R, $0.2 \mu \mathrm{M}$ AoPR1F/AoPR1R, $0.1 \mu \mathrm{M}$ AMEL3/ITS4, and $0.05 \mu \mathrm{M}$ AITSF/ AITSR (Table 2). The amplification program consisted of an initial step at $95^{\circ} \mathrm{C}$ for $15 \mathrm{~min}$; followed by 40 cycles of denaturation at $94^{\circ} \mathrm{C}$ for $30 \mathrm{~s}$, annealing at $58^{\circ} \mathrm{C}$ for $90 \mathrm{~s}$, and extension at $72^{\circ} \mathrm{C}$ for $90 \mathrm{~s}$; with a final extension at $72^{\circ} \mathrm{C}$ for $10 \mathrm{~min}$. This procedure was carried out in a PTC 100 thermocycler (MJ Research, Waltham, MA). Once validated for the seven abovementioned strains, the multiplex PCR method for species identification was used to examine all of the 318 Armillaria samples collected in this study.

Microsatellite typing of A. mellea and A. gallica isolates. All fungal samples classified as $A$. gallica and $A$. mellea according to the multiplex PCR were further genotyped at the loci AgSSR21, $-29,-62,-65$, and -74 using A. gallica microsatellites (14). In a preliminary test, we found that these five simple-sequence repeat (SSR) loci could be transferred from A. gallica to A. mellea. The microsatellite PCR procedures were performed in a reaction mixture (final volume of $10 \mu \mathrm{l}$ ) consisting of $0.1 \mathrm{mM}$ dNTP, $1.5 \mathrm{mM}$ $\mathrm{MgCl}_{2}, 0.2 \mu \mathrm{M}$ each microsatellite primer (14), $0.7 \mathrm{U}$ of GoTaq polymerase, and $2 \mu \mathrm{l}$ of Armillaria DNA from the second elution (DNA not quantified) in $1 \times$ GoTaq reaction buffer (Promega, Milano, Italy). The forward primers AgSSR21, -29, -62, -65, and
-74 were 5' labeled with the fluorescent dyes HEX, 6FAM, NED, HEX, and 6FAM, respectively (Applied Biosystems, Foster City, CA). The PCR amplification was performed according to the following program: an initial step at $94^{\circ} \mathrm{C}$ for $2 \mathrm{~min}$; followed by 37 cycles of denaturation at $94^{\circ} \mathrm{C}$ for $30 \mathrm{~s}$, annealing at $58^{\circ} \mathrm{C}$ for $40 \mathrm{~s}$, and extension at $72^{\circ} \mathrm{C}$ for $30 \mathrm{~s}$; with a final extension at $72^{\circ} \mathrm{C}$ for $7 \mathrm{~min}$. Amplicons from different loci were pooled on the basis of their size and fluorophore dye; equal volumes of PCR products of loci AgSSR21, -29, and -62 were pooled in one tube and PCR products of loci 65 and 74 were pooled in a second tube. Each pooled sample $(1 \mu \mathrm{l})$ was mixed with $10 \mu \mathrm{l}$ of formamide and $0.2 \mu \mathrm{l}$ of ROX-500 ladder and separated by electrophoresis in an ABI PRISM 3730 capillary sequencer (Applied Biosystems). Raw data were analyzed using Genescan 3.7 and microsatellite fragment sizes were scored using Genotyper 3.6 (Applied Bio-

TABLE 2. Polymerase chain reaction primers targeting Armillaria rDNA that were used in this study

\begin{tabular}{llc}
\hline Primer & \multicolumn{1}{c}{ Sequence $\left(5^{\prime} \rightarrow 3^{\prime}\right)$} & Amplicon size $(\mathrm{bp})$ \\
\hline AgPR1F & GATTCGAAAGGGTAGGCTAACAACA & 354 \\
AgPR1R & CCTCGAAACCTAAGTAAACGGTTGA & $\ldots$ \\
AoPR1F & AAGAGCGAGTTAATAAGTGATTTG & 283 \\
AoPR1R & CAACTTTCGCTATAGGCCAAATCAA & $\ldots$ \\
AITSF & CAGGTAGGACTACCCGCTGA & $934-961$ \\
AITSR & GTTCGATTAGTCTTTCGCCC & $\ldots$ \\
AIGSF & AGACGACTTGAATGGGAACGGG & $470-500$ \\
AIGSR & TTGCCGTTCAAAWWTTGAAC & $\ldots$ \\
\hline
\end{tabular}

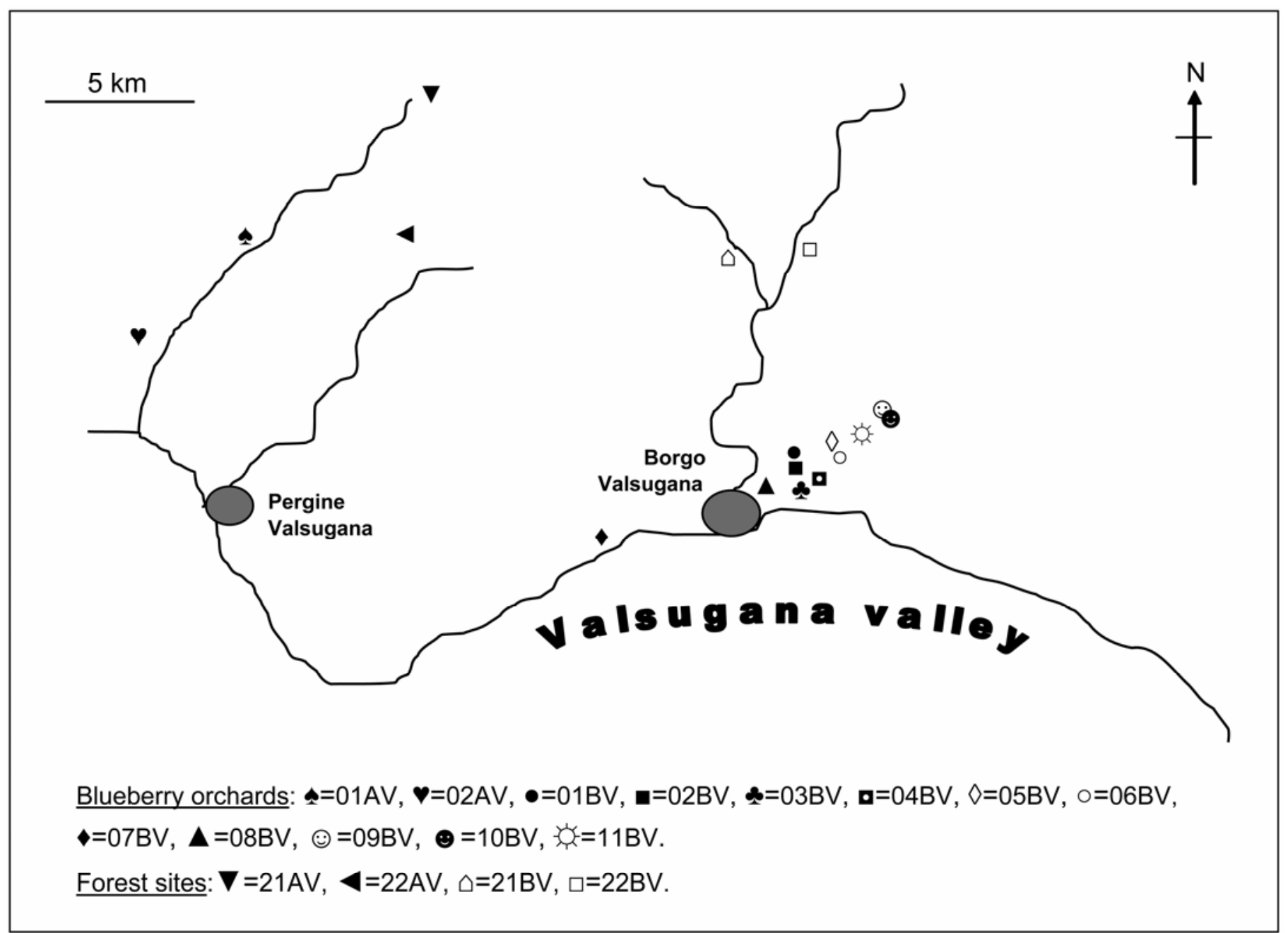

Fig. 1. Map of the Valsugana Valley. Symbols represent the highbush blueberry orchards in which Armillaria root rot was found in 2006 and the forest sites where growers collect bark to mulch the blueberry plants. 
systems). Armillaria isolates showing different SSR allelic patterns were designated as different genotypes. Conversely, individuals sharing the same SSR pattern were considered as having the same genotype. Shannon's equitability index $\left(\mathrm{E}_{\mathrm{H}}\right)$ was used to assess population heterogeneity (19).

Identification of other Armillaria spp. To identify those Armillaria samples that could not be classified as A. mellea, A. gallica, or A. ostoyae in the previous multiplex assay, an rDNA sequencing assay was developed. Armillaria $26 \mathrm{~S}$ rRNA and IGS1 sequences deposited in the NCBI GenBank with the accession codes AF163617, AF451823, and DQ115587 (A. mellea); AY509173, AF451830, and DQ336613 (A. gallica); AY509157, AF451815, and DQ115575 (A. ostoyae); AY509191, AF451835, and DQ115588 (A. tabescens); AY509184, AF451807, and DQ115583 (A. cepistipes Velen.); and AF451801, DQ115576, and AF243056 (A. borealis) were aligned using ClustalW. The universal Armillaria primer pair AIGSF and AIGSR (Table 2) was designed based on conserved regions of the rDNA of the abovementioned Armillaria strains, encompassing variable regions. Primer specificity was tested on A. mellea CBS 102.91, A. tabescens CBS 129.26, A. ostoyae ATCC strain 66009, and A. gallica 14A. The PCR procedure was performed in a final volume of $20 \mu \mathrm{l}$, consisting of $1 \times$ PCR buffer, $0.1 \mathrm{mM} \mathrm{dNTP,} 1.5 \mathrm{mM}$ $\mathrm{MgCl}_{2}, 0.2 \mathrm{mM}$ each of the primers (AIGSF and AIGSR), $0.7 \mathrm{U}$ of GoTaq polymerase (Promega), and $2 \mu$ of Armillaria DNA. The amplification was performed according to the program used for the microsatellite typing. The PCR products were purified using MultiScreen $\mathrm{PCR}_{\mu 96}$ Filter Plates (Millipore, Vimodrone, Italy) according to the manufacturer's instructions. Cycle sequencing was carried out using the AIGSF and AIGSR primers and the BigDye Terminator kit (v3.1; Applied Biosystems). The cycle sequencing products were purified using the PCR Cleanup Filter Plates kit (Millipore) and loaded into an ABI 3100 Prism Sequencer (Applied Biosystems) according to the manufacturer's instructions. Sequences were edited using Sequencher (version 4.8; GeneCodes, Madison, WI) and then compared with sequences in the NCBI GenBank database using the Mega Blast program (2).

\section{RESULTS}

Identification of infected blueberry fields and disease development. Of the $\approx 350$ blueberry fields in Valsugana, 23 were considered to be potentially infected based on information received from crop advisors and growers. Further inspection confirmed infection in 13 of these fields. Most of the fields in which infection was confirmed are located around the town of Borgo Valsugana, in the lowest part of the Valsugana Valley (Fig.

TABLE 3. Total number and percentages of healthy, stunted, and dead plants in the infected blueberry crops in the Valsugana Valley, Italy, in 2006

\begin{tabular}{lcccc}
\hline & \multicolumn{4}{c}{ Blueberry plants } \\
\cline { 2 - 5 } Code & Total no. & Healthy $(\%)$ & Stunted $(\%)$ & Dead $(\%)$ \\
\hline 01 AV & 1,833 & 96.4 & 3.0 & 0.6 \\
02 AV & 530 & 83.4 & 16.4 & 0.2 \\
01 BV & 141 & 90.7 & 7.8 & 1.5 \\
02 BV & 198 & 76.2 & 18.7 & 5.1 \\
03 BV & 545 & 98.5 & 0.8 & 0.7 \\
04 BV & 302 & 93.7 & 5.3 & 1.0 \\
05 BV & 410 & 78.5 & 19.0 & 2.5 \\
06 BV & 571 & 92.3 & 7.5 & 0.2 \\
07 BV & 300 & 85.0 & 15.0 & 0.0 \\
08 BV & 547 & 74.5 & 20.0 & 5.5 \\
09 BV & 491 & 87.4 & 12.2 & 0.4 \\
10 BV & 231 & 81.8 & 16.9 & 1.3 \\
11 BV & 381 & 97.1 & 2.9 & 0.0 \\
Average & $\ldots$ & 87.3 & 11.2 & 1.5 \\
Total & 6,480 & $\ldots$ & $\ldots$ & $\ldots$ \\
\hline
\end{tabular}

1). The average percentage of stunted plants in the infected fields was $11 \%$. The highest rate of infection $(20 \%)$ was observed in field 08BV (Table 3). The incidence of dead plants in each field was generally very low ( 0 to $2.5 \%$ ), with values $>5 \%$ in only two fields. All of the infected fields were planted between 1997 and 2003 and the first Armillaria root rot symptoms were generally observed 3 to 4 years after planting (Table 1). The disease usually started from individual blueberry plants in several points inside and at the margins of the fields and developed in patches. In all, 3 to 75 Armillaria samples were collected in each of the 13 infected blueberry fields (291 samples) and 2 to 14 Armillaria samples were collected from each of the forest locations (27 samples) (Tables 4 and 5). A 10 to $20 \%$ increase in the incidence of stunted plants was observed between 2003 and 2006 in the plots that were surveyed annually (05BV and 08BV). During the 4-year survey, the incidence of dead plants in these plots increased from 1.5 to 2.5 and from 4.5 to $5.5 \%$ in fields $05 \mathrm{BV}$ and $08 \mathrm{BV}$, respectively.

Multiplex PCR for identifying Armillaria spp. The multiplex PCR procedure allowed us to differentiate between A. mellea, A gallica, and A. ostoyae; it provided clearly distinguishable species-specific amplicons $(\approx 700,354$, and $283 \mathrm{bp}$, respectively) (Table 2; Fig. 2). The universal primer pair AITSF and AITSR allowed the PCR amplification $(\approx 950 \mathrm{bp})$ of the ITS1 and ITS2 loci of all four Armillaria spp. tested (Fig. 2, only one representative of each species is shown).

Identification of Armillaria spp. in blueberry fields and forest sites in the Valsugana Valley. After the validation of the multiplex PCR assay, the same approach was used to sort the 318 Armillaria samples collected in the Valsugana Valley by species. The dominant Armillaria spp. were A. gallica (in 242 samples) and $A$. mellea (in 71 samples). We did not identify any representatives of A. ostoyae (Tables 4 and 5). A. gallica was identified on blueberry plants (in 170 samples); in the bark heap in field 04BV (in 4 samples); on bark heaps in the forest (in 25 samples); on chestnuts, hazelnuts, stone fruit trees, and forest tree stumps (in 24 samples); and on the bark spread in the blueberry rows (in 19 samples). A. mellea was found infecting blueberry plants (in 65 samples), cherry trees (in four samples), and a bark heap in the forest (in two samples) but was not found on the bark spread in the rows. Five Armillaria samples could not be identified using the multiplex PCR procedure. DNA from these samples was sequenced at the 26S rRNA and IGS1 loci and the resulting sequences were compared with others in the GenBank database. The highest levels of sequence similarity (99\%) were found with the species A. gemina Bérubé \& Dessur. (one sample), A. cepistipes (one sample), A. cepistipes or A. sinapina Bérubé \& Dessur. (two samples), and A. calvescens Bérubé \& Dessur. or $A$. sinapina (one sample). For the last three Armillaria isolates, only an ambiguous species determination was possible. All of these rare species were collected from blueberry plants. Up to three Armillaria spp. coexisted in the same field (01AV) but, generally, one or two species were identified. In each field, a single species, either A. mellea (e.g., in 02BV) or A. gallica (e.g., in 02AV) usually dominated the population (Table 4).

Microsatellite typing of the $\boldsymbol{A}$. mellea and A. gallica isolates. Microsatellite analyses were carried out exclusively on individuals of the most frequently observed species, A. mellea and $A$. gallica. Two of the five examined loci were monomorphic (AgSSR29, allele size $=155 \mathrm{bp}$ and AgSSR65, allele size $=159$ bp) while the remaining three were polymorphic. Up to three alleles were identified for each of the loci AgSSR21 (allele size range: 114 to $140 \mathrm{bp}$; number of alleles: 20) and AgSSR74 (allele size range: 116 to $144 \mathrm{bp}$; number of alleles: 20). The locus AgSSR62 (allele size range: 124 to $155 \mathrm{bp}$; number of alleles: 20) showed two alleles per individual. At the three polymorphic loci, 24 alleles were found to be common to both A. gallica and $A$. mellea while 13 were A. mellea specific and 23 were A. gallica specific. The comparison of the allelic patterns among Armillaria 
isolates allowed the identification of 57 genotypes among the 313 A. mellea and A. gallica isolates collected (Tables 4 and 5). In all, 42 genotypes were identified among the samples collected in the crop and 15 genotypes were identified among the forest-collected isolates. Three to eight Armillaria genotypes were identified in each blueberry field (on blueberry plants and other inoculum sources). The genotypic diversity $\left(\mathrm{E}_{\mathrm{H}}\right)$ within fields (samples from blueberry plants only) was $<0.3$ in five cases and reached 1.0 as a maximum. $E_{H}$ within other inoculum sources was 0.15 to 0.55 . In the two forest locations at which more than eight samples were collected, the genotypic diversity was moderate to high $\left(0.5<\mathrm{E}_{\mathrm{H}}<\right.$ 0.8 ). No individual genotype was ever observed in more than one blueberry field or present in both field and forest sites. In seven of eight Valsugana fields in which Armillaria individuals were isolated from both blueberry and possible inoculum sources, one or two genotypes out of three to eight were found to be present on both blueberry plants and in the bark heap, bark in rows, and other infected plant species (all of them were trees) (Table 4). Two-thirds (five of eight) of the genotypes collected from trees in the immediate vicinity of the fields also infected blueberry plants. Similarly, two-thirds of the genotypes collected from the bark spread in blueberry rows were also identified on blueberry plants (Table 4). In one case (04BV), a genotype identified in the bark heap was also identified on blueberry plants and on the bark spread in the rows. A single genotype identified in field $02 \mathrm{AV}$ was found to be present on an old chestnut stump, on bark in the rows, and on blueberry plants.

\section{DISCUSSION}

In this study, a fast and reliable PCR-based approach for Armillaria spp. identification was successfully implemented. The multiplex PCR procedure allowed the identification of the three Armillaria spp. that had been previously reported on highbush blueberry (i.e., A. mellea, A. gallica, and A. ostoyae) (4,20). This species identification was achieved using a single reaction per root sample, representing an improvement over the previously established and time-consuming protocols based on singleplex
PCR procedures (25) and restriction fragment length polymorphisms (10). In $98 \%$ of the samples analyzed, either A. mellea or A. gallica was identified, greatly reducing the need for further identification procedures (IGS1 sequencing). In other studies, in which higher species diversity is expected, it would be preferable to test the multiplex PCR procedure on a larger set of known Armillaria spp. than those shown in Figure 2. As reported by Sicoli et al. (25), because of the great similarity in the sequences of $A$. borealis and A. ostoyae and between the sequences of $A$. cepistipes and A. gallica, we found the identification of these species to be problematic. The multiplex PCR procedure provided an internal positive control for each PCR reaction (Armillaria ITS, locus AITS). A totally failed multiplex PCR reaction is a warning sign indicating that the DNA extraction procedure may not have been successful or that polymerase inhibitors may have been present in the DNA eluate and does not imply the absence of Armillaria spp. on root samples (9).

Two of the five isolates that were not classified as A. gallica, A. mellea, or A. ostoyae were identified as A. gemina and A. cepistipes using IGS1 sequencing. The remaining three isolates were only ambiguously identified; they are most likely A. cepistipes or A. sinapina (two isolates) and A. calvescens or A. sinapina (one

TABLE 5. Armillaria spp., samples, genotypes, and genotypic diversity (Shannon index) identified in four forest locations in the Valsugana Valley, Italy, in 2006

\begin{tabular}{llccc}
\hline Location code & Species $^{\mathrm{y}}$ & $\begin{array}{c}\text { No. of } \\
\text { samples }\end{array}$ & $\begin{array}{c}\text { No. of } \\
\text { genotypes }^{\mathrm{z}}\end{array}$ & $\begin{array}{c}\text { Shannon } \\
\text { index }\end{array}$ \\
\hline $21 \mathrm{AV}$ & A. gallica & 14 & 8 & 0.77 \\
$22 \mathrm{AV}$ & A. gallica & 2 & 1 & 0.00 \\
$21 \mathrm{BV}$ & A. gallica & 7 & 3 & 0.55 \\
& A. mellea & 2 & 2 & 1.00 \\
22BV & A. gallica & 2 & 1 & 0.00 \\
Total & $\ldots$ & 27 & 15 & $\ldots$ \\
\hline
\end{tabular}

${ }^{y}$ Multiplex polymerase chain reaction was used to identify Armillaria gallica and A. mellea.

${ }^{\mathrm{z}}$ Microsatellite markers were used to differentiate between the different genotypes of A. gallica and A. mellea.

TABLE 4. Location code, number of Armillaria spp. samples, species, number of genotypes, and genotypic diversity (Shannon index) in 13 blueberry fields on blueberry plants and on other sources surrounding fields (trees, bark in the rows, and bark heaps) in the Valsugana Valley, Italy, in 2006

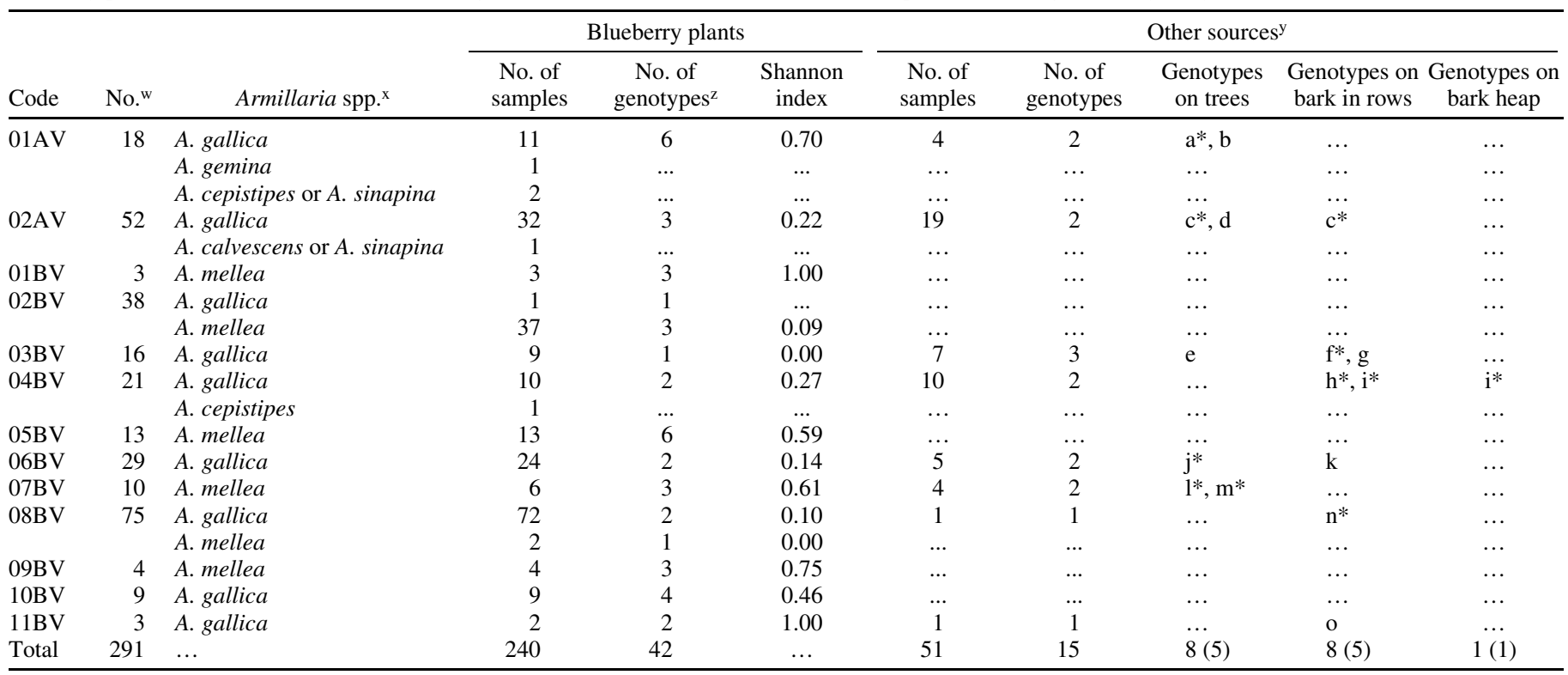

${ }^{\mathrm{w}}$ Number of samples.

${ }^{x}$ Multiplex polymerase chain reaction was used to identify the Armillaria spp. A. gallica and A. mellea. The species A. gemina and A. cepistipes, as well as the ambiguously identified A. cepistipes or A. sinapina and A. calvescens or A. sinapina, were identified following 26S rRNA and IGS1 sequencing and the comparison of the resulting sequences with those in the National Center for Biotechnology Information GenBank database.

${ }^{y}$ Different genotypes on other sources are marked with letters; asterisk $\left(^{*}\right)$ indicates that the same genotype was found also on blueberry plants.

${ }^{\mathrm{z}}$ Microsatellite markers were used to differentiate between the different genotypes of A. gallica and A. mellea. 
isolate). A. gemina, A. sinapina, and A. calvescens are not yet reported in Europe (16), whereas A. cepistipes is both a European and an extra-European species (12). Therefore, if we theoretically exclude species that are not yet present in Europe, it is reasonable to assume that three of these five isolates are most likely $A$. cepistipes. If further studies will confirm the identity of $A$. gemina, we can hypothesize that it could have been introduced from North America with nursery plant material, which is a common practice in the studied area. As Kim et al. (12) also found, it is not possible to distinguish between those species using IGS1 sequences, and sequencing the ITS and 5.8S loci does not provide a more accurate identification of the species. The use of other DNA markers, such as amplified fragment length polymorphisms, may allow for more reliable identification in difficult cases.

As described above, the main species found in the 13 fields and four forest locations were A. mellea and A. gallica. The former is a species that is known to have a wide host range, which includes orchard trees $(6,24)$, while the latter is mainly a forest species that infects stressed hardwood and coniferous trees (14). The present study confirmed this previous observation, because A. mellea was found on blueberry plants, on cherry trees ( $07 \mathrm{BV})$, and in two forest samples. The fields hosting a widespread A. mellea clone were surrounded by other orchards or had been previously cultivated, usually with fruit trees. As expected, A. gallica was identified among the forest samples but it was also identified as the dominant species in eight blueberry fields. These particular crops directly neighbor forests, suggesting that A. gallica may have migrated from the forest into these fields or may have been present in the fields before the blueberry plantation was established. A. gallica may also have been introduced into the field via infected coniferous bark used as mulch, because this species was found in this bark.

La Porta et al. (13) in 2006 identified several Armillaria spp. among the rhizomorphs and fruiting bodies they collected from 40 forest sites in Trentino. In their study, the most frequently isolated species was A. cepistipes (61\%), followed by A. ostoyae (26\%), A. gallica (7.5\%), A. mellea (4.8\%), and A. borealis $(0.5 \%)$. The different results obtained in this study suggest that in each forest (and cultivated) area of the region there is probably a different predominant species of Armillaria (i.e., A. gallica and A. mellea in Valsugana Valley, which represents only a limited part of Trentino).

Microsatellite analysis allowed the study of the structures of the A. mellea and A. gallica populations. Up to now, Armillaria population structures were generally assessed using somatic incompatibility testing (26) and IGS sequencing (18). To the best of our knowledge, SSR markers have only been used once before for confirming the genetic homogeneity of A. ostoyae genets (30). Prior to this study, this method had never been used to examine $A$.

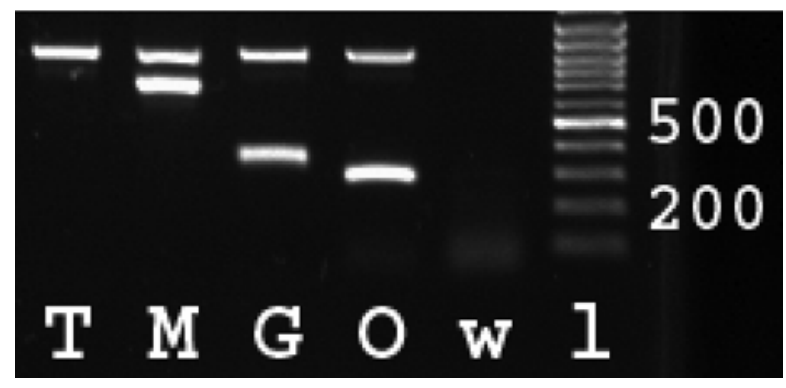

Fig. 2. Multiplex polymerase chain reaction for distinguishing Armillaria spp. The universal primers AITSF and AITSR were used to amplify the rDNA of Armillaria tabescens $(\mathrm{T})$, A. mellea $(\mathrm{M})$, A. gallica $(\mathrm{G})$, and A. ostoyae $(\mathrm{O})$. Species discrimination among A. mellea, A. gallica, and A. ostoyae was made possible by species-specific amplicon sizes (Table 2); w, water control; 1, 100-bp ladder. gallica. Five of the six A. gallica SSRs (14) were used successfully in this study, both for A. mellea and A. gallica. However, only three of these SSRs were polymorphic in the Valsugana Valley populations examined. This may be due to the relatively restricted geographical area in which the sampling was performed. The analysis of further Italian, other European countries, and global populations may reveal whether there is more diversity at those loci. The SSR markers AgSSR21 and -74 generated a complex banding pattern (more than two alleles per locus and concurrent one-base and two-base stuttering) that required a lot of attention during scoring. Despite their complexity, the determination of genotypes was still possible after cross-comparisons among banding patterns of different individuals. For studies of population genetics, the use of such SSRs is not recommended because a strictly diploid data set is often required.

The finding of more than two alleles per locus suggests polyploidization, locus duplications, or the sampling of more than a single genotype. This phenomenon has been previously observed in populations of Plasmopara viticola (22) and Phytophthora infestans $(5,29)$, in which it was assumed to be due to tetraploidy. Based on the currently available information, it is not possible to verify any similar hypothesis for the Armillaria spp. in the Valsugana samples.

Stunted and dead blueberry plants were located in close vicinity of one another, possibly indicating that Armillaria spp. infections started from a single plant and then spread to the surrounding plants by means of rhizomorphs. This same pattern was repeatedly observed in each of the infected fields, suggesting that the disease spread from different inoculum points.

In each of the 13 fields, a plot-specific Armillaria genotype was sampled multiple times (up to 62 times in $08 \mathrm{BV}$ ), indicating its widespread colonization of blueberry plants. The genotypes sampled less frequently were concentrated on single plants or groups of adjacent plants. That spatial pattern is consistent with the spatial structure reported by Worrall et al. (30) for A. ostoyae in an area in which a couple of more spatially restricted genotypes coexisted with one widely spread genotype. Pertot et al. (18), who analyzed the spatial distribution of A. mellea in the large Italian viticultural area of the Trentino region, also observed both a high level of genetic diversity and vineyard-specific genotypes. Individual $A$. mellea clones (defined as individuals that have the same IGS1 sequence and belong to the same SI group) were never found in different vineyards. Also, in the present study, individual Armillaria genotypes were never found in more than one field, even when fields were located only $30 \mathrm{~m}$ apart from one another (e.g., 09 and 10BV). This may reflect the slow growth rate of Armillaria spp., which can be only a few centimeters per year $(11,21)$. Interestingly, the same genotypes were not even found in different fields belonging to the same grower (e.g., 01-02 BV and 09-10 BV), indicating that the movement of Armillaria spp. with infected plants and contaminated farm machinery and tools may be a rare event.

The spatial spread of A. gallica was found to be similar to that of $A$. mellea (data not shown), even though the two species have different growth rates and different pathogenicity patterns. $A$. gallica commonly produces a more extensive network of rhizomorphs in soil than A. mellea; therefore, it may have an advantage in terms of contacting new substrate and colonizing larger areas $(15,27)$. On the other hand, A. gallica is considered to be a weak pathogen, whereas $A$. mellea is a virulent species on forest and orchard trees $(6,14,15)$. These complementary characteristics probably give the two Armillaria spp. comparable spreading abilities in blueberry fields.

Armillaria spp.-infected trees growing in the proximity of recently established blueberry fields were assumed to be a potential inoculum source. This hypothesis was confirmed in four of the five fields in which infected trees were identified. One to two Armillaria genotypes were found on both infected trees and 
blueberry plants. The presence of infected trees, preexisting the establishment of the blueberry fields, let us speculate a directional vegetative expansion of Armillaria spp. from these trees to the blueberry plants rather than the opposite direction. The presence of the same genotypes on trees and blueberry indicates that infected trees are a potential source of inoculum that must be taken into consideration when new blueberry plantations are established. Surrounding trees should be inspected and infected roots should be removed before new blueberry plantations are established. Agronomical practices carried out in the field in previous seasons should also be considered when selecting a blueberry plantation site. Stone fruit, apple and pear trees, and grapevines are particularly susceptible to the disease and should be carefully inspected. Burying infected roots and stumps of old fruit or forest trees before the new planting could represent a dangerous practice, which may promote the spread and development of Armillaria populations. For example, roots of hazelnut trees and black locust trees had been previously buried in field $08 \mathrm{BV}$, which was the most seriously infected field, and this practice probably promoted the spread of the pathogen in the soil (one genotype was widespread throughout the plot) and the subsequent infection of blueberry roots.

Similar to old infected trees, bark heaps at the edges of the field (in one of the survey locations) and bark spread in rows (in four of six cases) were shown to be additional sources of inoculum. In these cases, one or two of the genotypes identified on the bark heap or on the bark in the rows were also identified on blueberry roots. A. gallica, which produces abundant rhizomorphs, seems to grow better than A. mellea on coniferous bark. It produces nets of rhizomorphs that hold bark pieces together. A. gallica was identified in 48 bark samples (bark heaps in the field, in the forest, and on bark in the rows). In contrast, two samples of A. mellea were isolated from bark heaps in the forest, and this species was never identified on bark in the rows or bark heaps in the field. Visual bark inspection, vapor sterilizing the bark, or inoculating the bark with biocontrol agents before spreading it along the crop rows may help reduce the spread of A. gallica into blueberry fields.

According to our sampling, no individual genotypes were recovered from both bark in the fields and bark in the forest. It should be mentioned that the bark that was spread in the rows was collected in the forest before we made our bark collections, thus reducing the probability of our finding genotypes common to both areas. Some genotypes observed on blueberry were not found on any of the other possible inoculum sources in or around the crop. This may be due to the relatively small number of samples collected from the bark heaps, the bark in the rows, and the surrounding trees. Nevertheless, it is also possible that the genotypes that were recovered from blueberry but not from the putative sources of inoculum may be indigenous to the area, having colonized the area prior to the establishment of the blueberry fields.

This research demonstrates that highbush blueberry is susceptible to Armillaria spp. infection but, to date, in the Trentino region of Italy, this infection has been limited to a few fields. This study also included the development of a rapid tool for the identification of Armillaria spp. that can easily be implemented in studies involving other infected areas and other hosts. Microsatellite typing showed that the A. mellea and A. gallica populations in the Valsugana Valley are genetically diverse and that individual genotypes are spread over relatively small areas.

\section{ACKNOWLEDGMENTS}

This research was supported by SafeCrop Centre, funded by the autonomous Province of Trento. We thank advisors A. Frontuto and S. Conci, L. Palmieri, and A. Pergher for their support of this research.

\section{LITERATURE CITED}

1. Aguin-Casal, O., Mansilla-Vazquez, J. P., and Sainz-Oses, M. J. 2006. In vitro selection of an effective fungicide against Armillaria mellea and control of white root rot of grapevine in the field. Pest Manage. Sci. 62:223-228.

2. Altschul, S. F., Madden, T. L., Schaer, A. A., Zhang J., Zhang Z., and Miller, W. 1997. Gapped BLAST and PSI-BLAST: a new generation of protein database search programs. Nucleic Acids Res. 25:3389-3402.

3. Baumgartner, K., and Rizzo, D. M. 2002. Spread of Armillaria root disease in a California vineyard. Am. J. Enol. Viticult. 53:197-203.

4. Caruso, F. L. 1995. Armillaria root rot. Pages 22-23 in: Compendium of Blueberry and Cranberry Diseases. F. L. Caruso and D. C. Ramsdell, eds. American Phytopathological Society Press, St. Paul, MN.

5. Chacon Acosta, G. M. 2007. Variability of Phytophthora infestans sensu lato in the highland tropics of Ecuador. A dissertation submitted to the Swiss Federal Institute of Technology-Zurich, for the degree of Doctor of Sciences. Doctoral Thesis ETH No. 17035, available at http://ecollection.ethbib.ethz.ch/ecol-pool/diss/fulltext/eth17035.pdf.

6. Chillali, M., Wipf, D., Guillamin, J. G., Mohammed, C., and Botton, B. 1998. Delineation of the European Armillaria species based on the sequences of the internal transcribed spacer (ITS) of ribosomal DNA. New Phytol. 138:553-561.

7. Fox, R. T. V. 2000. Armillaria Root Rot: Biology and Control of Honey Fungus. Intercept, Andover, UK.

8. Gobbin, D., Pertot, I., and Gessler, C. 2003. Identification of microsatellite markers for Plasmopara viticola and establishment of a high throughput method for SSR analysis. Eur. J. Plant Pathol. 109:153-164.

9. Gobbin, D., Rezzonico, F., and Gessler, C. 2007. Development of a quantitative competitive PCR assay for the quantification of the biocontrol agent Pseudomonas fluorescens Pf153 in soil which is unaffected by variability in DNA extraction efficiency. Soil Biol. Biochem. 39:1609-1619.

10. Harrington, T. C., and Wingfield, B. D. 1995. A PCR-based identification method for species of Armillaria. Mycologia 87:280-288.

11. Kable, P. F. 1974. Spread of Armillaria sp. in a peach orchard. Trans. Br. Mycol. Soc. 62:89-98.

12. Kim, M. S., Klopfenstein, N. B., Hanna, J. W., and McDonald, G. I. 2006. Characterization of North American Armillaria species: genetic relationships determined by ribosomal DNA sequences and AFLP markers. For. Pathol. 36:145-164.

13. La Porta, N., Grillo, R., and Korhonen, K. 2006. Identificazione delle specie di Armillaria in Trentino ed interazioni tra specie di Armillaria ed Heterobasidion. Page 33 in: Proc. XVI Convegno Nazionale di Micologia, Firenze, Italy.

14. Lefrancois, J. B., Lung-Escarmant, B., and Langrell, S. R. H. 2002. Development of novel polymerase chain reaction (PCR) based microsatellite markers in Armillaria gallica by cross-species amplification and species-specific cloning. Mol. Ecol. Notes 2:182-184.

15. Morrison, D. J. 2004. Rhizomorph growth habit, saprophytic ability and virulence of 15 Armillaria species. For. Pathol. 34:15-26.

16. Pegler, D. N. 2000. Taxonomy, nomenclature and description of Armillaria. Pages 81-93 in: Armillaria Root Rot: Biology and Control of Honey Fungus. R. T. V. Fox, ed. Intercept, Andover, UK.

17. Perez Sierra, A., and Gorton, C. 2005. Survival of honey fungus in wood and bark chip mulches. Plantsman 4:204-207.

18. Pertot, I., Gobbin, D., De Luca, F., and Prodorutti, D. 2008. Methods to assess the incidence of Armillaria root rot across wide viticultural areas and the pathogen's genetic diversity and spatial-temporal pattern in northern Italy. Crop Prot. 27:1061-1070.

19. Pielou, E. C. 1966. The measurement of diversity in different types of biological collections. J. Theor. Biol. 13:131-144.

20. Prodorutti, D., Palmieri, L., Gobbin, D., and Pertot, I. 2006. First report of Armillaria gallica on highbush blueberry (Vaccinium corymbosum L.) in Italy. Plant Pathol. 55:583.

21. Rizzo, D. M., Whiting, E. C., and Elkins, R .B. 1998. Spatial distribution of Armillaria mellea in pear orchards. Plant Dis. 82:1226-1231.

22. Rumbou, A., and Gessler, C. 2006. Particular structure of Plasmopara viticola populations evolved under Greek island conditions. Phytopathology 96:501-509.

23. Saville, B. J., Yoell, H., and Anderson, J. B. 1996. Genetic exchange and recombination in populations of the root-infecting fungus Armillaria gallica. Mol. Ecol. 5:485-497.

24. Sicoli, G., Annese, V., de Gioia, T., and Luisi, N. 2002. Armillaria pathogenicity tests on oaks in southern Italy. J. Plant Pathol. 84:107-111.

25. Sicoli, G., Fatethi, J., and Stenlid, J. 2003. Development of speciesspecific PCR primers on rDNA for the identification of European Armillaria species. For. Pathol. 33:287-297.

26. Smith, M. L., Bruhn, J. N., and Anderson, J. B. 1994. Relatedness and spatial distribution of Armillaria genets infecting red pine seedlings. 
Phytopathology 84:822-829.

27. Termorshuizen, A. J. 2000. Ecology and epidemiology of Armillaria. Pages 45-63 in: Armillaria Root Rot: Biology and Control of Honey Fungus. R. T. V. Fox, ed. Intercept, Andover, UK.

28. Thompson, J. D., Higgins, D. G., and Gibson, T. J. 1994. CLUSTAL W: Improving the sensitivity of progressive multiple sequence alignment through sequence weighting, position-specific gap penalties and weight matrix choice. Nucleic Acids Res. 22:4673-4680.

29. Tooley, P. W., Therrien, C. D., Sim, J .H., O'Sullivan E., and Dowley, L. J. 1993. Mating-type, nuclear DNA content and isozyme genotypes of Irish isolates of Phytophthora infestans. Mycol. Res. 97:1131-1134.

30. Worrall, J. J., Sullivan, K. F., Harrington, T. C., and Steimel, J. P. 2004. Incidence, host relations and population structure of Armillaria ostoyae in Colorado campgrounds. For. Ecol. Manage. 192:191-206. 